\title{
Biochemical Changes in the Leaves of Wheat Plants Infected by Pyricularia oryzae
}

\author{
Daniel Debona, Fabrício Ávila Rodrigues, Jonas Alberto Rios, and Kelly Juliane Telles Nascimento
}

Viçosa Federal University, Department of Plant Pathology, Laboratory of Host-Parasite Interaction, 36570-000, Viçosa, MG, Brazil. Accepted for publication 3 August 2012.

\begin{abstract}
Debona, D., Rodrigues, F. Á., Rios, J. A., and Nascimento, K. J. T. 2012. Biochemical changes in the leaves of wheat plants infected by Pyricularia oryzae. Phytopathology 102:1121-1129.

Blast, caused by the fungus Pyricularia oryzae, is a major disease of the wheat crop in the Brazilian Cerrado and represents a potential threat to world wheat production. However, information about the wheat- $P$. oryzae interaction is still limited. In this work, the activities of the enzymes superoxide dismutase (SOD), catalase (CAT), peroxidase (POX), glutathione-S-transferase (GST), ascorbate peroxidase (APX), glutathione reductase (GR), and glutathione peroxidase (GPX) and the concentrations of superoxide $\left(\mathrm{O}_{2}^{-}\right)$, hydrogen peroxide $\left(\mathrm{H}_{2} \mathrm{O}_{2}\right)$, and malondialdehyde (MDA) as well as the electrolyte leakage (EL) were studied in wheat plants 'BR 18' and 'BRS 229', which are susceptible and partially resistant, respectively, to leaf blast at the vegetative growth stage, during the infection process of $P$. oryzae. The blast severity in BRS 229 was $50 \%$

lower than in BR 18 at $96 \mathrm{~h}$ after inoculation (hai). The activities of SOD, POX, APX, and GST increased for both cultivars in the inoculated plants compared with noninoculated plants and the increases were more pronounced for BRS 229 than for BR 18 at 96 hai. The GR and CAT activities only increased in inoculated plants from BRS 229 at 96 hai. For BR 18 , the GR activity was not influenced by plant inoculation, and the CAT activity was lower in inoculated plants. The GPX activity only increased in inoculated plants from BR 18 at 48 and 72 hai. The $P$. oryzae infection increased the $\mathrm{O}_{2}^{-}, \mathrm{H}_{2} \mathrm{O}_{2}$, and MDA concentrations and EL. However, the greater increases of the SOD, POX, APX, GST, GR, and CAT activities for BRS 229 compared with BR 18 contributed to the lower $\mathrm{O}_{2}^{-}, \mathrm{H}_{2} \mathrm{O}_{2}$, and MDA concentrations and EL verified in the former. These results show that a more efficient antioxidative system in the removal of excess of reactive oxygen species generated during the infection process of $P$. oryzae limits the cellular damage caused by the fungus, thus contributing to greater wheat resistance to blast.
\end{abstract}

Blast, caused by the fungus Pyricularia oryzae Cavara (teleomorph: Magnaporthe grisea (T. T. Hebert) M. E. Barr), is an agronomically important disease of wheat (Triticum aestivum L.) and can cause yield losses $\leq 70 \%$ (32). Blast symptoms on leaves begin as gray-green and water-soaked lesions, with dark-green borders after they are completely expanded (67). On glumes, elliptical lesions with a gray center surrounded by brown borders are observed (67). The symptoms on spikes are evidenced as a bright black point on rachis (67). The rachis colonization by $P$. oryzae decreases nutrient translocation to the grains, which become shriveled in appearance, small, misshapen, and underweight (32).

The absence of cultivars with a desirable level of resistance to blast and the low efficiency of the available fungicides $(18,32$ 34,72 ) makes blast control very difficult to achieve. Today, the release of wheat cultivars with a high level of resistance to blast has been a priority for wheat breeding programs, especially to areas with severe epidemics of blast (18). Some studies have demonstrated the existence of cultivars partially resistant to blast $(7,18,73)$ but the mechanisms involved in this resistance is absent.

Plants under stress conditions, such as pathogen attack, are induced to increase the production of reactive oxygen species (ROS) (50). Hydrogen peroxide $\left(\mathrm{H}_{2} \mathrm{O}_{2}\right)$, a type of ROS, is directly involved in the death of both pathogens and host cells and in the oxidative cross-links between proteins in the cell walls, which become more resistant to degradation by lytic enzymes and nonselective toxins released by the pathogen (53). Although $\mathrm{H}_{2} \mathrm{O}_{2}$ is essential for signaling and plant defense against pathogen infec-

Corresponding author: F. A. Rodrigues; E-mail address: fabricio@ufv.br

http://dx.doi.org/10.1094/PHYTO-06-12-0125-R

(c) 2012 The American Phytopathological Society tion, it can react with the superoxide $\left(\mathrm{O}_{2}^{-}\right)$radical or with metal ions to form a hydroxyl radical $\left(\mathrm{OH}^{\bullet}\right)$, which is extremely toxic to pathogens in addition to enhancing the cytotoxicity of $\mathrm{H}_{2} \mathrm{O}_{2}$ (49). Oxidative stress causes lipid peroxidation in the cell membrane and damage to pigments, proteins, and nucleic acids (5).

To remove the excess ROS generated during the host-pathogen interaction, plants have developed nonenzymatic and enzymatic mechanisms (69). Superoxide dismutase (SOD), catalase (CAT), peroxidase (POX), glutathione-S-transferase (GST), ascorbate peroxidase (APX), glutathione reductase (GR), and glutathione peroxidase (GPX) are the enzymes commonly involved in the host defense against oxidative stress $(6,22,40,55,60,71)$. SOD, which is involved in the dismutation of the $\mathrm{O}_{2}^{-}$radical to molecular oxygen and $\mathrm{H}_{2} \mathrm{O}_{2}(31)$, constitutes the first line of defense against oxidative stress (12). The enzymes involved in the removal of $\mathrm{H}_{2} \mathrm{O}_{2}$ include CAT, POX, APX, GST, GPX, and GR $(6,22,40,55,60,73)$.

Even though changes in the antioxidative system of plants during pathogen infection have been well documented $(1,2,21$, 47 ), only a few studies have investigated the relationship of these changes to host resistance. To the best of our knowledge, information about the changes in the antioxidative system and the concentration of ROS in the leaves of wheat plants during the infectious process of $P$. oryzae is missing. Therefore, this study aimed to determine the activity of antioxidative enzymes, the concentration of ROS, and damage to the cell membrane in two cultivars with different levels of resistance to blast.

\section{MATERIALS AND METHODS}

Plant growth. Wheat seed from 'BR 18' and 'BRS 229' were surface-sterilized in $10 \%\left(\mathrm{vol} \mathrm{vol}^{-1}\right) \mathrm{NaOCl}$ for $2 \mathrm{~min}$, rinsed in sterilized water for $3 \mathrm{~min}$, and sown in plastic pots $(20 \mathrm{~cm}$ in 
diameter) (Ecovaso, Jaguariúna, São Paulo, Brazil) filled with $1 \mathrm{~kg}$ of substrate made from a 1:1:1 mixture of pine bark, peat, and expanded vermiculite (Tropstrato; Vida Verde, Mogi Mirim, São Paulo, Brazil). A previous study showed that BR 18 and BRS 229 were susceptible and partially resistant, respectively, to leaf blast at the vegetative growth stage (18). In total, $1.63 \mathrm{~g}$ of calcium phosphate monobasic was added to each plastic pot. In all, 12 seeds were sown per pot and, 5 days after seedling emergence, each pot was thinned to six seedlings. During seed germination, the temperature was $25 \pm 5^{\circ} \mathrm{C}$, the relative humidity was $65 \pm 5 \%$, and sunlight conditions were provided inside the greenhouse. The substrate in each pot was fertilized with a nutrient solution containing the following: $\mathrm{KCl}$ at $6.4 \mathrm{~g} \mathrm{liter}^{-1}, \mathrm{~K}_{2} \mathrm{SO}_{4}$ at $3.48 \mathrm{~g} \mathrm{liter}^{-1}, \mathrm{MgSO}_{4} \cdot 7 \mathrm{H}_{2} \mathrm{O}$ at $5.01 \mathrm{~g} \mathrm{liter}^{-1},\left(\mathrm{NH}_{2}\right)_{2} \mathrm{CO}$ at $2.03 \mathrm{~g}$ liter ${ }^{-1}, \mathrm{NH}_{4} \mathrm{MO}_{7} \mathrm{O}_{24} \cdot 4 \mathrm{H}_{2} \mathrm{O}$ at $0.009 \mathrm{~g} \mathrm{liter}^{-1}, \mathrm{H}_{3} \mathrm{BO}_{3}$ at $0.054 \mathrm{~g}$ liter ${ }^{-1}, \mathrm{ZnSO}_{4} \cdot 7 \mathrm{H}_{2} \mathrm{O}$ at $0.222 \mathrm{~g} \mathrm{liter}^{-1}, \mathrm{CuSO}_{4} \cdot 5 \mathrm{H}_{2} \mathrm{O}$ at $0.058 \mathrm{~g}$ liter ${ }^{-1}$, and $\mathrm{MnCl}_{2} \cdot 4 \mathrm{H}_{2} \mathrm{O}$ at $0.137 \mathrm{~g} \mathrm{liter}^{-1}$ (75). A volume of $15 \mathrm{ml}$ of nutrient solution containing $\mathrm{FeSO}_{4} \cdot 7 \mathrm{H}_{2} \mathrm{O}$ at $0.27 \mathrm{~g} \mathrm{liter}^{-1}$ and ethylenediaminetetraacetic acid (EDTA) bisodic at $0.37 \mathrm{~g}$ liter $^{-1}$ was also applied after seedlings emergence. The nutrient solution was prepared using deionized water. After seedling emergence, $30 \mathrm{ml}$ of the nutrient solution was applied to each pot every week. The plants were watered as needed with deionized water.

Inoculum production and inoculation procedure. All the leaves from each plant were inoculated with a conidial suspension of $P$. oryzae $\left(10^{5}\right.$ conidia $\left.\mathrm{ml}^{-1}\right)$ at 30 days after emergence (growth stage 19) (76). Suspension $(25 \mathrm{ml})$ was applied as a fine mist to the adaxial leaf blades of each plant until runoff using a VL Airbrush atomizer (Paasche Airbrush Co., Chicago). Gelatin (1\%, $\mathrm{wt} \mathrm{vol}^{-1}$ ) was added to the suspension to aid conidial adhesion to the leaf blades. Immediately after inoculation, the plants were transferred to a growth chamber with a temperature of $25 \pm 2{ }^{\circ} \mathrm{C}$ and a relative humidity of $90 \pm 5 \%$ and were subjected to an initial 24-h dark period. After this period, the plants were transferred to a plastic mist growth chamber (MGC) inside a greenhouse for the duration of the experiment. The MGC was made of wood ( $2 \mathrm{~m}$ wide, $1.5 \mathrm{~m}$ high, and $5 \mathrm{~m}$ long) and covered with 100 -mm-thick transparent plastic. The temperature inside the MGC ranged from $25 \pm 2{ }^{\circ} \mathrm{C}$ (day) to $20 \pm 2^{\circ} \mathrm{C}$ (night). The relative humidity was maintained at $92 \pm 3 \%$ using a misting system in which nozzles (model NEB-100; KGF Company, São Paulo, Brazil) sprayed mist every $30 \mathrm{~min}$ above the plant canopy. The relative humidity and temperature were measured with a thermohygrograph (TH-508; Impac, São Paulo, Brazil). The maximum natural photon flux density at plant canopy height was approximately $900 \mu \mathrm{mol} \mathrm{m}^{-2} \mathrm{~s}^{-1}$.

Assessment of blast severity. The fourth and fifth leaves from the base of each plant per replication of each treatment were marked and used to evaluate the blast severity at 72 and $96 \mathrm{~h}$ after inoculation (hai) using the scale proposed by the International Rice Research Institute (43).

Determination of enzyme activities. Samples from the fourth and fifth leaves from the base of each plant (a total of 12 leaves per replication of each treatment) were collected at 48, 72, and 96 hai. The leaf samples were kept in liquid nitrogen during sampling and then stored at $-80^{\circ} \mathrm{C}$ until further analysis.

To determine the activities of SOD (EC 1.15.1.1), CAT (EC 1.11.1.6), POX (EC 1.11.1.7), GST (EC 2.5.1.18), APX (EC 1.11.1.11), and GPX (EC 1.11.1.9), $300 \mathrm{mg}$ of leaf tissue (mix of the 12 leaves collected per replication of each treatment) was ground into a fine powder in a mortar and pestle with liquid nitrogen. The fine powder was homogenized in an ice bath in $2 \mathrm{ml}$ of a solution containing $50 \mathrm{mM}$ potassium phosphate buffer $(\mathrm{pH}$ 6.8), $0.1 \mathrm{mM}$ EDTA, $1 \mathrm{mM}$ phenylmethylsulfonyl fluoride (PMSF), and 2\% (wt $\mathrm{vol}^{-1}$ ) polyvinylpolypyrrolidone (PVPP). The homogenate was centrifuged at $12,000 \times g$ for $15 \mathrm{~min}$ at $4^{\circ} \mathrm{C}$, and the supernatant was used as a crude enzyme extract. To determine the GR (EC 1.8.1.7) activity, $300 \mathrm{mg}$ of leaf tissue was ground as described above. The fine powder was homogenized in an ice bath in $2 \mathrm{ml}$ of a solution containing $100 \mathrm{mM}$ potassium phosphate buffer (pH 7.5), $0.1 \mathrm{mM}$ EDTA, $1 \mathrm{mM} D L$-dithiothreitol, $1 \mathrm{mM}$ PMSF, and 2\% (wt vol ${ }^{-1}$ ) PVPP. The homogenate was centrifuged as described previously.

The SOD activity was determined by measuring its ability to photochemically reduce the $p$-nitrotetrazole blue (NTB) (20). The reaction was started after the addition of $60 \mu$ of the crude enzyme extract to $1.94 \mathrm{ml}$ of a mixture containing $50 \mathrm{mM}$ potassium phosphate buffer ( $\mathrm{pH} 7.8$ ), $13 \mathrm{mM}$ methionine, $75 \mu \mathrm{M}$ NTB, $0.1 \mathrm{mM}$ EDTA and $2 \mu \mathrm{M}$ riboflavin. The reaction occurred at $25^{\circ} \mathrm{C}$ under a $15-\mathrm{W}$ lamp light. After $10 \mathrm{~min}$ of light exposure, the light was interrupted, and the production of formazan blue, which resulted from the photoreduction of NTB, was monitored by the increase in absorbance at $560 \mathrm{~nm}$ in spectrophotometer (Evolution 60; Thermo Fisher Scientific Inc., MA) (31). The reaction mixture for the control samples was kept in darkness for $10 \mathrm{~min}$, and the absorbance measured at $560 \mathrm{~nm}$. The values obtained were subtracted from the values obtained from the samples of the replications of each treatment exposed to light. One unit of SOD was defined as the amount of enzyme necessary to inhibit NBT photoreduction by $50 \%$ (10).

The CAT activity was determined following the method of Cakmak and Marschner (15). The reaction mixture consisted of $50 \mathrm{mM}$ potassium phosphate buffer $\left(\mathrm{pH} \mathrm{6.8)}\right.$ ) and $20 \mathrm{mM} \mathrm{H}_{2} \mathrm{O}_{2}$ in a volume of $1.95 \mathrm{ml}$. The reaction was initiated after the addition of $50 \mu \mathrm{l}$ of the crude enzyme extract, and the CAT activity was determined by the rate of $\mathrm{H}_{2} \mathrm{O}_{2}$ decomposition at $240 \mathrm{~nm}$ for $1 \mathrm{~min}$ at $25^{\circ} \mathrm{C}$. An extinction coefficient of $36 \mathrm{M}^{-1} \mathrm{~cm}^{-1}$ (3) was used to calculate the CAT activity, which was expressed as millimoles per minute per milligram of protein.

The POX activity was assayed following the colorimetric determination of pyrogallol oxidation according to Kar and Mishra (45). The reaction mixture contained $25 \mathrm{mM}$ potassium phosphate (pH 6.8), $20 \mathrm{mM}$ pyrogallol, and $20 \mathrm{mM} \mathrm{H}_{2} \mathrm{O}_{2}$ in a volume of $1.98 \mathrm{ml}$. The reaction was started after the addition of $15 \mu \mathrm{l}$ of the crude enzyme extract, and the POX activity was determined through the absorbance of colored purpurogallin recorded at $420 \mathrm{~nm}$ for $1 \mathrm{~min}$ at $25^{\circ} \mathrm{C}$. An extinction coefficient of $2.47 \mathrm{mM}^{-1} \mathrm{~cm}^{-1}$ (17) was used to calculate the POX activity, which was expressed as micromoles of purpurogallin produced per minute per milligram of protein.

The GST activity was determined using the methodology proposed by Habig et al. (36). In total, $150 \mu$ of the crude enzyme extract was added to $1.35 \mathrm{ml}$ of the mixture containing $50 \mathrm{mM}$ potassium phosphate buffer $(\mathrm{pH} 6.5)$ and $50 \mathrm{mM}$ reduced glutathione $(\mathrm{GSH})$. The reaction was initiated after the addition of $500 \mu \mathrm{l}$ of $30 \mathrm{mM}$ 1-chloro-2,4-dinitrobenzene and then incubated for $4 \mathrm{~min}$ at $25^{\circ} \mathrm{C}$. The absorbance was measured at $340 \mathrm{~nm}$ over 3 min. An extinction coefficient of $9.6 \mathrm{mM}^{-1} \mathrm{~cm}^{-1}$ (36) was used to determine the GST activity, which was expressed as micromoles per minute per milligram of protein.

The APX activity was determined according to method of Nakano and Asada (59). The reaction mixture consisted of $50 \mathrm{mM}$ potassium phosphate buffer ( $\mathrm{pH} 6.8), 1 \mathrm{mM} \mathrm{H}_{2} \mathrm{O}_{2}$, and $0.8 \mathrm{mM}$ ascorbate in a volume of $1.95 \mathrm{ml}$. The reaction was started after the addition of $50 \mu \mathrm{l}$ of the crude enzyme extract. The APX activity was measured by the rate of ascorbate oxidation at $290 \mathrm{~nm}$ for $1 \mathrm{~min}$ at $25^{\circ} \mathrm{C}$. An extinction coefficient of $2.8 \mathrm{mM}^{-1} \mathrm{~cm}^{-1}$ (59) was used to calculate the APX activity, which was expressed as micromoles per minute per milligram of protein.

To determine the GR activity, the reaction was started after the addition of $100 \mu \mathrm{l}$ of the crude enzyme extract to a volume of $1.9 \mathrm{ml}$ of a mixture containing $100 \mathrm{mM}$ potassium phosphate ( $\mathrm{pH}$ 7.5), $1 \mathrm{mM}$ EDTA, $1 \mathrm{mM}$ oxidized glutathione (GSSG), and $0.1 \mathrm{mM}$ NADPH prepared in $0.5 \mathrm{mM}$ Tris- $\mathrm{HCl}$ buffer $(\mathrm{pH} 7.5)$ according to Carlberg and Mannervik (16). The decrease in absorbance was determined at $340 \mathrm{~nm}$ for $1 \mathrm{~min}$ at $30^{\circ} \mathrm{C}$. An extinc- 
tion coefficient of $6.22 \mathrm{mM}^{-1} \mathrm{~cm}^{-1}$ (27) was used to calculate the GR activity, which was expressed as micromoles per minute per milligram of protein.

The GPX activity was estimated after the addition of $100 \mu \mathrm{l}$ of the crude enzyme extract to a mixture containing $50 \mathrm{mM}$ potassium phosphate buffer ( $\mathrm{pH} 7.0$ ), $1 \mathrm{mM}$ EDTA, $0.114 \mathrm{M} \mathrm{NaCl}$, $1 \mathrm{mM}$ GSH, $0.2 \mathrm{mM}$ NADPH, $0.25 \mathrm{mM} \mathrm{H}_{2} \mathrm{O}_{2}$, and $1 \mathrm{U}$ of GR (58). The decrease in absorbance was measured at $340 \mathrm{~nm}$ for $1 \mathrm{~min}$ at $30^{\circ} \mathrm{C}$. An extinction coefficient of $6.22 \mathrm{mM}^{-1} \mathrm{~cm}^{-1}$ (4) was used to calculate the GPX activity, which was expressed as nanomoles per minute per milligram of protein.

For each enzyme activity, four separate extractions were performed for samples from each treatment. Each extraction was read three times. A boiled extract was used as the blank treatment during the determination of the activity of each enzyme. The soluble protein concentrations of the extracts were measured by the method of Bradford (13) using bovine serum albumin as the standard protein.

Determination of superoxide concentration. In total, $100 \mathrm{mg}$ of leaf tissue was incubated in a volume of $2 \mathrm{ml}$ of a mixture containing $100 \mu \mathrm{M}$ ethylenediaminetetraacetic acid disodium salt ( $\mathrm{Na}_{2} \mathrm{EDTA}$ ), $20 \mu \mathrm{M} \beta$-nicotinamide adenine nucleotide reduced (NADH), and $20 \mathrm{mM}$ sodium phosphate buffer (pH 7.8) (57). The mixture was prepared in septum-stoppered flasks. The reaction was initiated after the addition of $100 \mu \mathrm{l}$ of $25.2 \mathrm{mM}$ epinephrine in $0.1 \mathrm{~N} \mathrm{HCl}$ using a chromatography syringe. The samples were incubated for $5 \mathrm{~min}$ at $28^{\circ} \mathrm{C}$ under shaking. Then, the leaf tissues were carefully removed using a plain sterile wood stem and, after $7 \mathrm{~min}$, the absorbance was measured at $480 \mathrm{~nm}$ for $5 \mathrm{~min}$. The controls corresponded to the mixtures without leaf tissue. The $\mathrm{O}_{2}{ }^{-}$ production was determined by the rate of adrenochrome accumulation (54). An extinction coefficient of $4.0 \times 10^{3} \mathrm{M}$ (11) was used to calculate the $\mathrm{O}_{2}{ }^{-}$concentration, which was expressed as millimoles per kilogram of fresh weight.

Determination of hydrogen peroxide concentration. In total, $100 \mathrm{mg}$ of leaf tissue was ground into a fine powder using a mortar and pestle with liquid nitrogen. The fine powder was homogenized in an ice bath in a volume of $2 \mathrm{ml}$ of a mixture containing $50 \mathrm{mM}$ potassium phosphate buffer $(\mathrm{pH} 6.5)$ and $1 \mathrm{mM}$ hydroxylamine. The homogenate was centrifuged at $10,000 \times g$ for $15 \mathrm{~min}$ at $4^{\circ} \mathrm{C}(46)$. In total, $100 \mu \mathrm{l}$ of the supernatant was added to a reaction mixture containing $100 \mu \mathrm{M}$ ferric ammonium sulfate $\left(\mathrm{FeNH}_{4}\left[\mathrm{SO}_{4}\right]\right), 25 \mathrm{mM}$ sulfuric acid, $250 \mu \mathrm{M}$ xylenol orange, and $100 \mathrm{mM}$ sorbitol in a volume of $2 \mathrm{ml}$ (30). The samples were kept in the dark for $30 \mathrm{~min}$ and then the absorbance was determined at $560 \mathrm{~nm}$. The controls for the reagents and crude extracts were prepared under the same conditions and subtracted from the sample. The $\mathrm{H}_{2} \mathrm{O}_{2}$ concentration, estimated based on a standard curve of $\mathrm{H}_{2} \mathrm{O}_{2}$, was expressed as micromoles per kilogram of fresh weight.

Determination of malondialdehyde concentration. Oxidative damage in the leaf cells was estimated as the content of total 2-thiobarbituric acid (TBA) reactive substances and expressed as equivalents of malondialdehyde (MDA) according to Cakmak and Horst (14). In total, $100 \mathrm{mg}$ of leaf tissue was ground into a fine powder using a mortar and pestle with liquid nitrogen. The fine powder was homogenized in $2 \mathrm{ml}$ of $0.1 \%\left(\mathrm{wt} \mathrm{vol}^{-1}\right.$ ) trichloracetic acid (TCA) solution in an ice bath. The homogenate was centrifuged at $12,000 \times g$ for $15 \mathrm{~min}$ at $4^{\circ} \mathrm{C}$. After centrifugation, $0.5 \mathrm{ml}$ of the supernatant was reacted with $1.5 \mathrm{ml}$ of TBA solution $\left(0.5 \%\right.$ in $20 \%$ TCA) for $30 \mathrm{~min}$ in a boiling water bath at $95^{\circ} \mathrm{C}$. After this period, the reaction was stopped in an ice bath. The samples were centrifuged at $9,000 \times g$ for $10 \mathrm{~min}$, and the specific absorbance was determined at $532 \mathrm{~nm}$. The nonspecific absorbance was estimated at $600 \mathrm{~nm}$ and subtracted from the specific absorbance value. An extinction coefficient of $155 \mathrm{mM}^{-1} \mathrm{~cm}^{-1}$ (38) was used to calculate the MDA concentration, which was expressed as micromoles per kilogram of fresh weight.
Determination of electrolyte leakage. The electrolyte leakage (EL) was determined according to the methodology of Lima et al. (48), with a few modifications. In total, 22 leaf discs $(8 \mathrm{~mm}$ in diameter) were collected from the fourth and fifth leaves from the base of each plant per replication and treatment at 72 and 96 hai. The leaf discs were thoroughly washed in deionized water immediately after being sampled. Then, the leaf discs were left to float on $60 \mathrm{ml}$ of deionized water in sealed glass for $4 \mathrm{~h}$ at $25^{\circ} \mathrm{C}$. After this period, the first value of conductivity (reading one) was obtained using a conductivity meter (Tecnopon mCA-150; MS Tecnopon Instrumentação Científica, São Paulo, Brazil). Next, the vials were transferred to an oven for $2 \mathrm{~h}$ at $90^{\circ} \mathrm{C}$ to obtain a new value for conductivity (reading two). The EL, given as a percentage, was obtained by dividing the value of reading one by the value of reading two.

Experimental design and data analysis. A two-by-two factorial experiment, consisting of two wheat cultivars (BR 18 and BRS 229) and plants that were noninoculated or inoculated with $P$. oryzae, was arranged in a completely randomized design with four replications. Each experimental unit consisted of one plastic pot with six plants. The experiment was repeated once. The data from all variables were analyzed by the analysis of variance (ANOVA), and the means from the noninoculated and inoculated plant treatments for each cultivar were compared by the $t$ test $(P \leq$ 0.05) using SAS (version 6.12; SAS Institute, Inc., Cary, NC). For the ANOVA, the design was considered to be a two-by-two factorial experiment, consisting of two wheat cultivars and two evaluation times (72 and 96 hai) for the blast severity. For the SOD, CAT, POX, GST, APX, GR, and GPX activities as well as the $\mathrm{O}_{2}^{-}, \mathrm{H}_{2} \mathrm{O}_{2}$, and MDA concentrations, the design was considered to be a two-by-two-by-three factorial experiment for the ANOVA, consisting of two wheat cultivars, noninoculated or inoculated plants, and three sampling times (48, 72, and 96 hai). For EL, it was considered to be a two-by-two-by-two factorial experiment for ANOVA, consisting of two wheat cultivars, noninoculated or inoculated plants, and two sampling times (72 and 96 hai).

\section{RESULTS}

Only the factors cultivars and evaluation times were significant for the blast severity (Table 1 ). The blast severity was significantly lower for BRS 229 than for BR 18, regardless of the evaluation time. For both cultivars, there was a significant increase in the blast severity from 72 to 96 hai. The blast severity increased from 10 to $13 \%$ for BRS 229 and from 24 to $32 \%$ for BR 18 from 72 to 96 hai. The blast severity showed a similar trend for the treatments, as determined in a preliminary experiment (data not shown).

At least one of the factors (cultivars, plant inoculation, or sampling times) and some of their interactions were significant for the activities of SOD, CAT, POX, GST, APX, GR, and GPX (Table 2), concentrations of $\mathrm{O}_{2}^{-}, \mathrm{H}_{2} \mathrm{O}_{2}$, and MDA (Table 3), and EL (Table 4). Alone, plant inoculation was the most important factor (higher $F$ values) that explained the variation in all the variables evaluated, except for CAT activity (Table 2 ) and the $\mathrm{H}_{2} \mathrm{O}_{2}$ concentration (Table 3). The cultivars-plant inoculation-sampling times interaction was not significant only for the CAT and GR activities (Table 2) and the $\mathrm{H}_{2} \mathrm{O}_{2}$ concentration (Table 3).

TABLE 1. Analysis of variance of the effects of cultivars and evaluation time for blast severity

\begin{tabular}{lcc}
\hline Sources of variation & df & $F$ values $^{\mathrm{a}}$ \\
\hline Cultivars (C) & 1 & $162.12^{*}$ \\
Evaluation time (ET) & 1 & $34.97^{*}$ \\
$\mathrm{C} \times$ ET & 1 & $1.25 \mathrm{~ns}$ \\
\hline
\end{tabular}

a Levels of probability: $\mathrm{ns}=$ not significant and $*=0.01$. 
The SOD activity significantly increased in the inoculated plants of BR 18 and BRS 229 compared with the noninoculated plants at 48, 72, and 96 hai (Fig. $1 \mathrm{~A}$ and B). The SOD activity increased by 40 and $28 \%$ at 48 hai, 44 and $53 \%$ at 72 hai, and 79 and $167 \%$ at 96 hai for the inoculated plants of BR 18 and BRS 229 , respectively, relative to the noninoculated plants.

The CAT activity significantly decreased in the inoculated plants of BR 18 compared with the noninoculated plants at 72 and 96 hai (Fig. 1C). For BRS 229, the CAT activity was higher for the inoculated plants than the noninoculated plants at both 48 and 96 hai (Fig. 1D).

The POX activity was higher in the inoculated plants of BR 18 and BRS 229 compared with the noninoculated plants at 48, 72, and 96 hai (Fig. $1 \mathrm{E}$ and F). The inoculated plants of BR 18 and BRS 229 showed increases of 239 and $189 \%$ at 48 hai, 400 and $368 \%$ at 72 hai, and 437 and $678 \%$ at 96 hai, respectively, for the POX activity compared with the noninoculated plants.

The inoculated plants of BR 18 and BRS 229 showed a significant increase in the GST activity compared with the noninoculated plants at 48, 72, and 96 hai (Fig. $1 \mathrm{G}$ and H). Increases of 92 and $102 \%$ at 48 hai, 50 and $140 \%$ at 72 hai, and 61 and $849 \%$ at 96 hai were obtained for the inoculated plants of BR 18 and BRS 229 , respectively, compared with the noninoculated plants.

There was a significant increase in the APX activity for the inoculated plants of BR 18 and BRS 229 at 48, 72, and 96 hai compared with the noninoculated plants (Fig. 1I and J). For the inoculated plants of BR 18 and BRS 229, there were increases of 70 and $44 \%$ at 48 hai, 29 and $79 \%$ at 72 hai, and 30 and $120 \%$ at 96 hai, respectively, for the APX activity compared with the noninoculated plants.

The GR activity was not affected by plant inoculation at 48, 72, and 96 hai for BR 18 and at 72 hai for BRS 229 (Fig. 1K and L). For BRS 229, the GR activity was higher for the inoculated plants than for the noninoculated plants at 48 and 96 hai.

For BR 18, the differences in the GPX activity between the inoculated and noninoculated plants were observed at 48 and 72 hai, with higher values of activity obtained for the former (Fig. 1M). For BRS 229, the GPX activity was not affected by plant inoculation with $P$. oryzae regardless of the sampling time (Fig. 1N).

Differences between the inoculated and noninoculated plants for the $\mathrm{O}_{2}^{-}$concentration were found at 72 and 96 hai for BR 18 and only at 96 hai for BRS 229, with the highest values occurring for the inoculated plants (Fig. 2A and B). The $\mathrm{O}_{2}{ }^{-}$concentration increased by 153 and $72 \%$ at 96 hai for the inoculated plants of BR 18 and BRS 229, respectively, compared with the noninoculated plants.

For the $\mathrm{H}_{2} \mathrm{O}_{2}$ concentration, there was a difference between the inoculated and noninoculated plants only for BR 18 at 72 and 96 hai, with the higher values occurring for the noninoculated and inoculated plants, respectively (Fig. 2C and D).

Regarding the MDA concentration, significant differences between the inoculated and noninoculated plants of BR 18 occurred at 48, 72, and 96 hai and only at 48 hai for BRS 229 (Fig. 2E and
F). For BR 18 and BRS 229, the MDA concentration was higher in the inoculated plants than in the noninoculated plants.

The inoculated plants of BR 18 and BRS 229 showed significant increases in EL at 72 and 96 hai compared with the noninoculated plants (Fig. 3). The EL increased by 124 and $87 \%$ at 72 hai and by 323 and $188 \%$ at 96 hai for the inoculated plants of BR 18 and BRS 229, respectively, compared with the noninoculated plants.

A preliminary experiment to determine the enzyme activities and the $\mathrm{O}_{2}^{-}, \mathrm{H}_{2} \mathrm{O}_{2}$, and MDA concentrations was performed and showed a similar trend for the treatments discussed above (data not shown).

\section{DISCUSSION}

The lower blast severity in the leaves of plants of BRS 229 compared with BR 18 confirmed the variation in resistance previously reported by Cruz et al. (18), which ranked them as moderately resistant (BRS 229) and susceptible (BR 18) to blast. Supporting the data provided by Cruz et al. (18), the present study brings novel evidence that a more efficient antioxidative system in the leaves of wheat plants from the moderately resistance BRS 229 that removes the excess ROS helps to limit the cellular damage that occurs during the infection process of $P$. oryzae and may be linked to the resistance of this cultivar. These results are supported by the data obtained in a series of preliminary experiments that showed similar trends (data not shown).

TABLE 3. Analysis of variance of the effects of cultivars (C), plant inoculation (PI), and sampling time (ST) on the concentration of superoxide $\left(\mathrm{O}_{2}^{-}\right)$, hydrogen peroxide $\left(\mathrm{H}_{2} \mathrm{O}_{2}\right)$, and malondialdehyde (MDA)

\begin{tabular}{lcccc}
\hline & & \multicolumn{3}{c}{$F$ values } \\
\cline { 3 - 5 } Sources of variation & df & $\mathrm{O}_{2}{ }^{-}$ & $\mathrm{H}_{2} \mathrm{O}_{2}$ & MDA \\
\hline $\mathrm{C}$ & 1 & $3.21 \mathrm{~ns}$ & $21.22^{* *}$ & $15.27 * *$ \\
$\mathrm{PI}$ & 1 & $19.32^{* *}$ & $0.36 \mathrm{~ns}$ & $51.82^{* *}$ \\
$\mathrm{ST}$ & 2 & $2.02 \mathrm{~ns}$ & $3.80^{*}$ & $39.46^{* *}$ \\
$\mathrm{C} \times \mathrm{PI}$ & 1 & $2.69 \mathrm{~ns}$ & $0.74 \mathrm{~ns}$ & $30.62^{* *}$ \\
$\mathrm{C} \times \mathrm{ST}$ & 2 & $4.15^{*}$ & $0.58 \mathrm{~ns}$ & $9.17 * *$ \\
$\mathrm{PI} \times \mathrm{ST}$ & 2 & $13.63^{* *}$ & $4.68 *$ & $4.49^{*}$ \\
$\mathrm{C} \times \mathrm{PI} \times \mathrm{ST}$ & 2 & $7.11^{* *}$ & $0.83 \mathrm{~ns}$ & $16.82^{* *}$ \\
\hline
\end{tabular}

a Levels of probability: $\mathrm{ns}=$ not significant, $*=0.05$, and $* *=0.01$.

TABLE 4. Analysis of variance of the effects of cultivars, plant inoculation, and sampling time on the electrolyte leakage

\begin{tabular}{lcr}
\hline Sources of variation & df & $F$ values $^{\mathrm{a}}$ \\
\hline Cultivars (C) & 1 & $13.74^{* *}$ \\
Plant inoculation (PI) & 1 & $286.49^{* *}$ \\
Sampling time (ST) & 1 & $98.87^{* *}$ \\
C $\times$ PI & 1 & $15.66^{* *}$ \\
C $\times$ ST & 1 & $8.25 * *$ \\
PI $\times$ ST & 1 & $68.55^{* *}$ \\
C $\times$ PI $\times$ ST & 1 & $7.13^{*}$ \\
\hline
\end{tabular}

${ }^{a}$ Levels of probability: $*=0.05$ and $* *=0.01$.

TABLE 2. Analysis of variance of the effects of cultivars (C), plant inoculation (PI), and sampling time (ST) on the activity of superoxide dismutase (SOD), catalase (CAT), peroxidase (POX), glutathione-S-transferase (GST), ascorbate peroxidase (APX), glutathione reductase (GR), and glutathione peroxidase (GPX)

\begin{tabular}{|c|c|c|c|c|c|c|c|c|}
\hline \multirow[b]{2}{*}{ Sources of variation } & \multirow[b]{2}{*}{ df } & \multicolumn{7}{|c|}{$F$ values $^{\text {a }}$} \\
\hline & & SOD & CAT & POX & GST & APX & GR & GPX \\
\hline $\mathrm{C}$ & 1 & $103.30^{* *}$ & $0.34 \mathrm{~ns}$ & $39.08 * *$ & $39.80 * *$ & $2.73 \mathrm{~ns}$ & $2.68 \mathrm{~ns}$ & $17.12 * *$ \\
\hline PI & 1 & $1,649.08 * *$ & $3.93 \mathrm{~ns}$ & $3,416.66^{* *}$ & $241.32 * *$ & $150.97 * *$ & $13.08 * *$ & $29.82 * *$ \\
\hline ST & 2 & $18.61 * *$ & $25.76 * *$ & $206.24 * *$ & $33.08 * *$ & $4.75^{*}$ & $4.31 *$ & $1.45 \mathrm{~ns}$ \\
\hline $\mathrm{C} \times \mathrm{PI}$ & 1 & $11.60 * *$ & $115.56^{* * *}$ & $29.20 * *$ & $18.59 * *$ & $7.61 * *$ & $5.17^{*}$ & $23.13 * *$ \\
\hline $\mathrm{C} \times \mathrm{ST}$ & 2 & $111.95 * *$ & $3.98 *$ & $56.52 * *$ & $13.99 * *$ & $4.62 *$ & $5.62 * *$ & $4.87 *$ \\
\hline $\mathrm{PI} \times \mathrm{ST}$ & 2 & $115.78 * *$ & $22.66 * *$ & $212.82 * *$ & $24.52 * *$ & $0.77 \mathrm{~ns}$ & $3.85^{*}$ & $1.28 \mathrm{~ns}$ \\
\hline $\mathrm{C} \times \mathrm{PI} \times \mathrm{ST}$ & 2 & $56.28 * *$ & $1.79 \mathrm{~ns}$ & $55.95 * *$ & $26.45 * *$ & $8.33^{* *}$ & $2.29 \mathrm{~ns}$ & $11.90 * *$ \\
\hline
\end{tabular}

${ }^{a}$ Levels of probability: $\mathrm{ns}=$ not significant, $*=0.05$, and $* *=0.01$. 
The ROS production is an important plant defensive response against pathogenic infection (50). However, ROS accumulation caused by the imbalance between its production and the host defense mechanisms in favor of the former results in oxidative stress that can damage the host tissue (48). Therefore, plants possess nonenzymatic and enzymatic mechanisms to keep the ROS levels approximately constant in the cells (69). The SOD activity increased in the leaves of wheat plants in response to $P$. oryzae
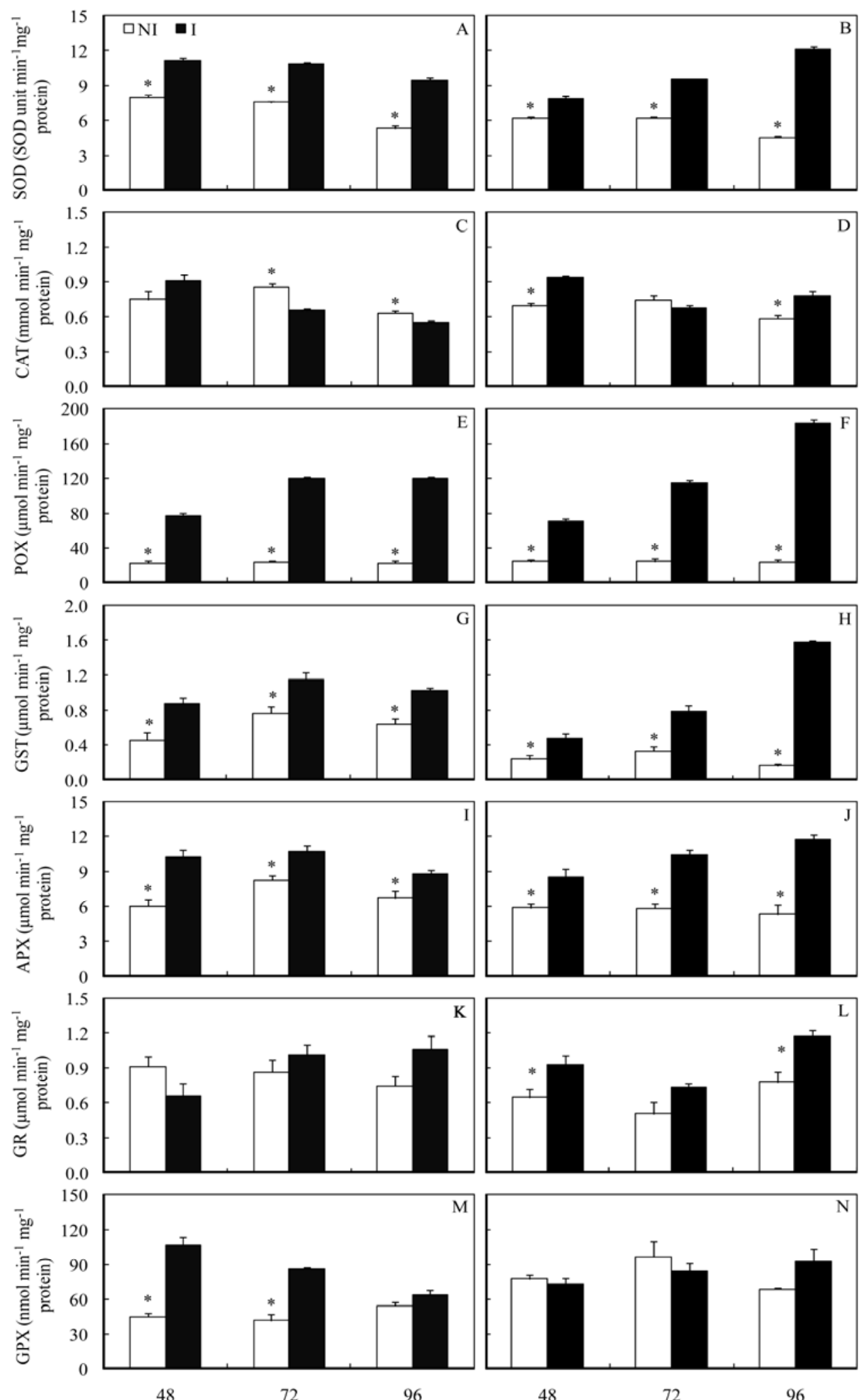

Hours after inoculation

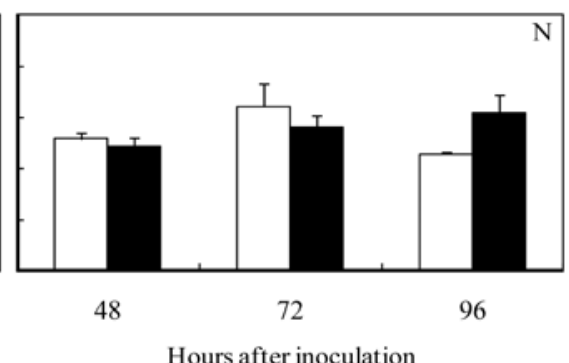

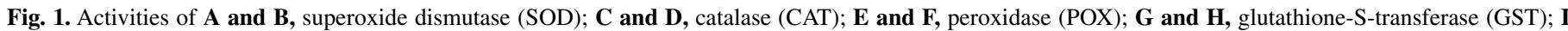

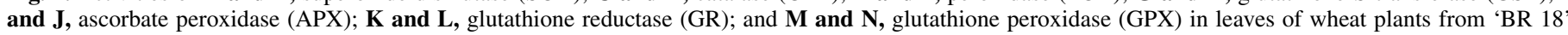

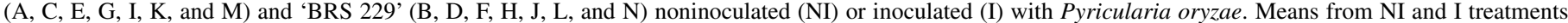

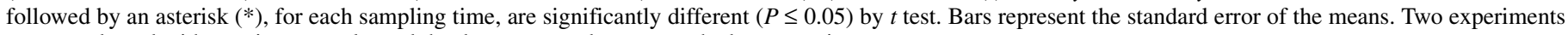
were conducted with consistent results and the data presented represent the best experiment. 
infection. In tomato, the peroxisomal SOD activity increased during the initial stage of Botrytis cinerea infection but decreased as the necrotic lesions appeared (47). However, in the present study, there was an increase in the SOD activity in the leaves of the inoculated plants as blast symptoms developed, which contrasted with the response in the leaves of noninoculated plants. Although the SOD activity increased in the leaves of the inoculated plants of both cultivars, its activity in BRS 229 showed a more prominent increase than in $\mathrm{BR} 18$, resulting in a lower $\mathrm{O}_{2}^{-}$concentration in the former. The SOD activity was also shown to increase in strawberry leaves infected by Mycosphaerella fragariae but the SOD activity for the resistant cultivars was greater than for the susceptible ones (24). Some fungal pathogens could benefit from an increase in ROS levels generated in the host cells during the defense against their infection as a facilitating factor to maximize their tissue colonization and nutrient uptake (35). Thus, higher SOD activity in resistant cultivars could be a strategy to restrict pathogen colonization because the excess ROS can be removed (24).

Among the enzymes involved in the removal of the excess $\mathrm{H}_{2} \mathrm{O}_{2}$ generated spontaneously or by $\mathrm{O}_{2}{ }^{-}$dismutation via SOD,
CAT plays a key role (55). In the present study, the increase in the $\mathrm{H}_{2} \mathrm{O}_{2}$ concentration observed in the leaves of the inoculated plants of BR 18 compared with the noninoculated plants at 96 hai was associated with a reduction in CAT activity, which confirms reports for other pathosystems. In the pea-Plum pox virus interaction, susceptible plants showed a decrease in the CAT activity and a concomitant increase in the $\mathrm{H}_{2} \mathrm{O}_{2}$ concentration only after the symptoms caused by this virus were evident (21). In the present study, the CAT activity only increased on leaves with intense blast symptoms at 48 hai. Based on a previous study in tomato (47), CAT and SOD activities were increased during the initial stage of $B$. cinerea infection and decreased after the necrotic lesion formation. The reduction in CAT activity could be a consequence of enhanced proteolysis caused by peroxisomal endopeptidases, which are induced by oxidative stress (63), as is the case of $P$. orzyae infection. Therefore, these results can explain the reduction in CAT activity in the leaves of wheat plants of BR 18 during the advanced stages of fungal infection.

Although the CAT activity decreased as the blast progressed in the leaves of the plants of BR 18, this result was not true for BRS

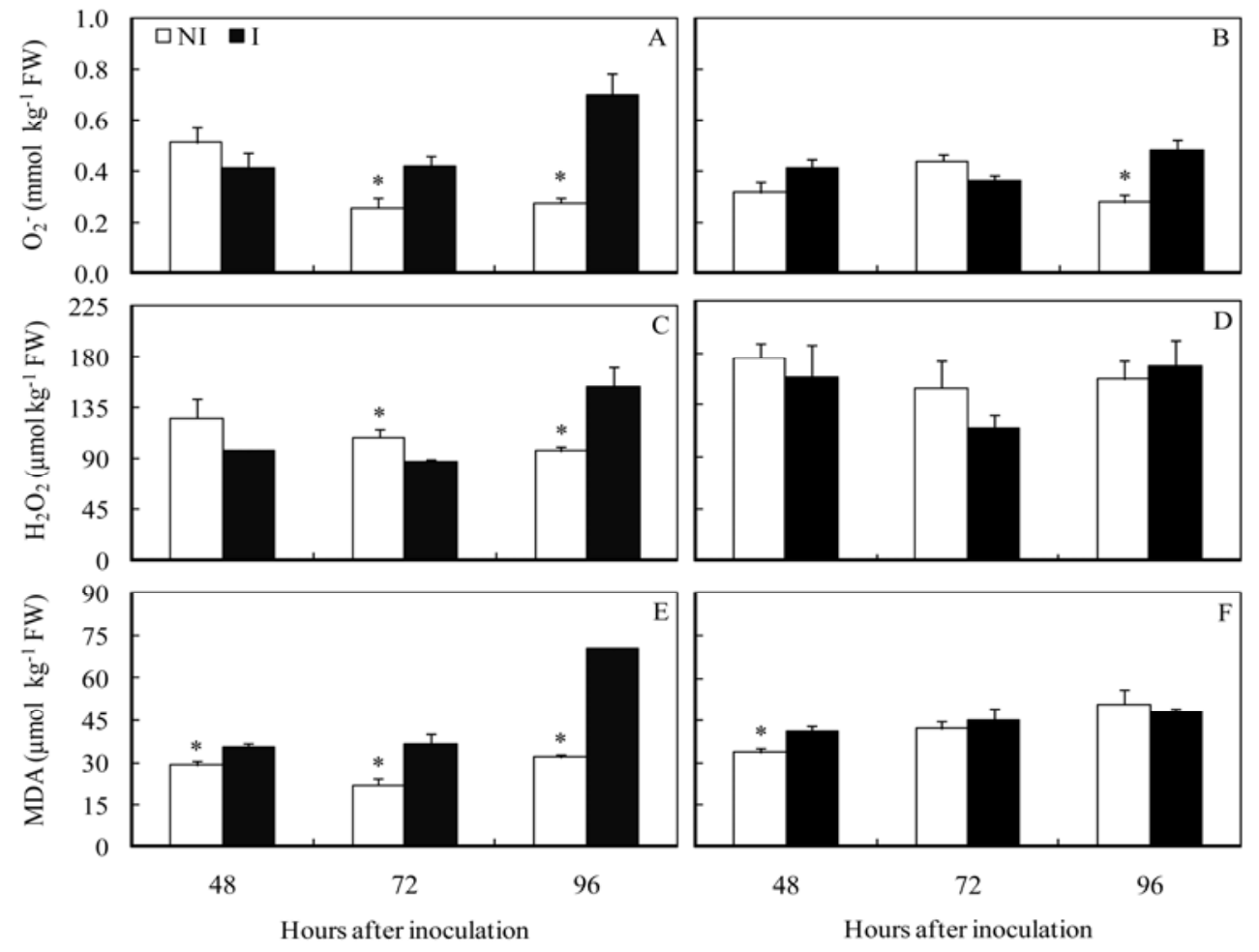

Fig. 2. Concentrations of $\mathbf{A}$ and $\mathbf{B}$, superoxide $\left(\mathrm{O}_{2}^{-}\right)$; $\mathbf{C}$ and $\mathbf{D}$, hydrogen peroxide $\left(\mathrm{H}_{2} \mathrm{O}_{2}\right)$; and $\mathbf{E}$, and $\mathbf{F}$, malondialdehyde (MDA) in leaves of wheat plants from 'BR 18' (A, C, and E) and 'BRS 229' (B, D, and F) noninoculated (NI) or inoculated (I) with Pyricularia oryzae. Means from NI and I treatments followed by an asterisk $(*)$, for each sampling time, are significantly different $(P \leq 0.05)$ by $t$ test. Bars represent the standard error of the means. FW $=$ fresh weight. Two experiments were conducted with consistent results and the data presented represent the best experiment.
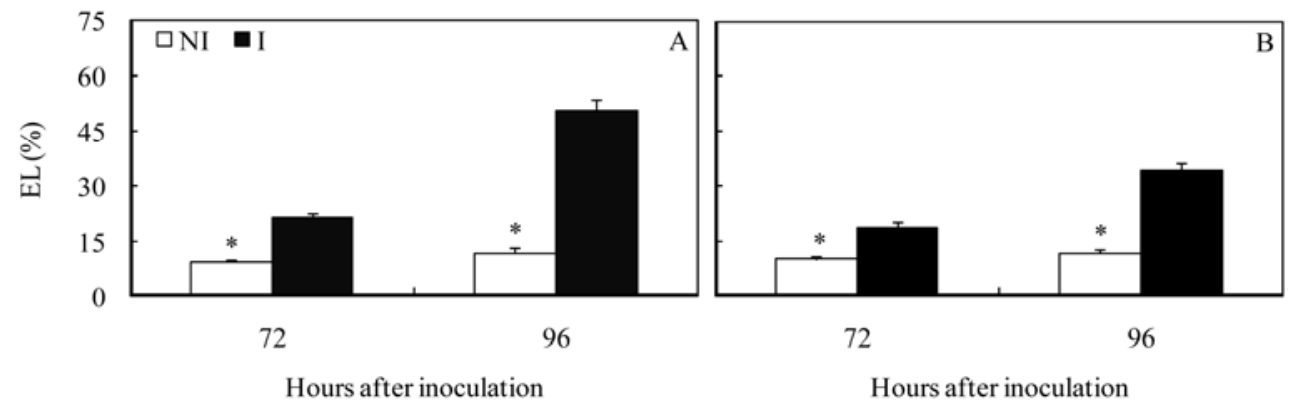

Fig. 3. Electrolyte leakage (EL) in leaves of wheat plants from A, 'BR 18' and B, 'BRS 229' noninoculated (NI) or inoculated (I) with Pyricularia oryzae. Means from NI and I treatments followed by an asterisk $(*)$, for each sampling time, are significantly different $(P \leq 0.05)$ by $t$ test. Bars represent the standard error of the means. Two experiments were conducted with consistent results and the data presented represent the best experiment. 
229. In this case, the CAT activity was higher in the inoculated than noninoculated leaves at 48 hai; however, no difference between the inoculated and noninoculated plants occurred for the $\mathrm{H}_{2} \mathrm{O}_{2}$ concentration. Therefore, the difference in the CAT activity between cultivars suggests that this enzyme plays a major role in the wheat resistance to blast. This result is in agreement with Magbanua et al. (50), who demonstrated that the CAT activity was higher in the leaves of maize lines resistant to Aspergillus flavus than in susceptible ones. However, the reduction of CAT activity usually increases plant resistance to pathogenic attack because plants can maintain high concentrations of $\mathrm{H}_{2} \mathrm{O}_{2}(50)$. Thus, the role of CAT in the plant-pathogen interaction seems to be more complex than for abiotic stress (47), which involves an association between CAT activity and plant tolerance $(56,61,74)$.

For the inoculated plants of both cultivars, there was a consistent increase in the POX, GST, and APX activities during the infectious process of $P$. oryzae. However, the increase was more pronounced for BRS 229 than for BR 18, suggesting that, in addition to CAT, those enzymes played key roles to maintain the $\mathrm{H}_{2} \mathrm{O}_{2}$ concentration constant in the inoculated plants of BRS 229.

In addition to the involvement of POX in the removal of $\mathrm{H}_{2} \mathrm{O}_{2}$, this enzyme plays an important role in plant defense against pathogens due to its participation in lignin biosynthesis (66). Hong-xia et al. (41) verified that the POX activity was more important for resistant than for susceptible wheat cultivars when infected by Rhizoctonia cerealis. The higher POX activity in the leaves of wheat plants during the late stages of $P$. oryzae infection was detrimental to the resistance against blast (75). These reports are in agreement with the data from the present study, which showed that the POX activity was maintained at a higher level in the leaves of wheat plants of BRS 229 than in BR 18 during the late stages of $P$. oryzae infection.

The GST is a large and diverse group of enzymes that catalyze the conjugation of reduced GSH to a variety of hydrophobic, electrophilic, and usually cytotoxic substrates $(22,64)$. GST reduces $\mathrm{H}_{2} \mathrm{O}_{2}$ and phospholipid hydroperoxides (26). The expression of the gst gene is responsive to biotic and abiotic stresses, suggesting its importance in plant defense $(23,52)$. Although whether the increase in GST activity confers increased tolerance to abiotic stresses is unknown (71), few studies have shown the activity of this enzyme in plants infected by pathogens, although the GST gene expression is induced in a wide range of plantpathogen interactions. The higher GST activity at 96 hai in the leaves of the plants of BRS 229 compared with BR 18 highlights its importance in ROS removal and, consequently, in the wheat resistance to blast.

The removal of $\mathrm{H}_{2} \mathrm{O}_{2}$ is the first step of the ascorbate-glutathione cycle $(9,27)$. This cycle comprises a series of redox reactions involving, in addition to APX, the enzymes monodehydroascorbate reductase, dehydroascorbate reductase, and GR $(27,59)$. APX is responsible for $\mathrm{H}_{2} \mathrm{O}_{2}$ removal in chloroplasts, peroxisomes, and mitochondria (65), using ascorbate as a specific electron donor to reduce $\mathrm{H}_{2} \mathrm{O}_{2}$ to water (8). The increases in the level of the apx transcripts and in the enzyme activity during the plantpathogen interactions have been well documented $(1,2,25,37$, 42,68). In the present study, the APX activity increased in response to $P$. oryzae infection in both wheat cultivars but its increase was higher in BRS 229 than in BR 18. Hückelhoven et al. (42) reported that the expression of the apx gene increased in the leaves of barley plants inoculated with Blumeria graminis $\mathrm{f}$. sp. hordei. Harrach et al. (37) observed that the activities of POX, APX, and GST were similarly altered in the leaves of barley plants inoculated with B. graminis f. sp. hordei.

The GR constitutes a group of nicotinamide dinucleotide (phosphate) $\mathrm{NAD}(\mathrm{P}) \mathrm{H}$-dependent enzymes that catalyze the reduction of GSSG to form two GSH molecules $(16,70)$. Hernández et al. (39) found that the GR activity in the resistant plants was higher than in the susceptible plants of apricot after inoculation with the
Plum pox virus. In the present study, the GR activity increased in the leaves of the inoculated plants of BRS 229 and BR 18 but was slightly greater for BR 229, confirming its high level of resistance to blast. The role of GR in plant resistance against pathogens is still unclear because no studies have demonstrated a close relationship between GR activity and an increase in host resistance. El-Zahabi et al. (25) did not find any difference in the GR activity in the leaves from three barley cultivars infected by virulent and avirulent isolates of $B$. graminis f. sp. hordei. In contrast, the GR activity only increased in the roots of chickpea plants infected by a virulent isolate of Fusarium oxysporum f. sp. ciceris (29).

The GPX comprises a family of isoenzymes using GSH to reduce $\mathrm{H}_{2} \mathrm{O}_{2}$ and lipid hydroperoxides to protect the cells against oxidative damage (65). According to Asada (9), the main functions of GPX in plants are lignin biosynthesis, degradation of indole-3-acetic acid, and resistance to pathogens. In the present study, the GPX activity increased only in the leaves of the plants of BR 18 inoculated with $P$. oryzae. The activity of peroxisomal GPX in the leaves of tomato plants increased during the early stages of infection by $B$. cinerea and decreased thereafter, as the severity of the gray mold reached high values (47).

An increase in both the $\mathrm{O}_{2}^{-}$and $\mathrm{H}_{2} \mathrm{O}_{2}$ concentrations in the leaves of BR 18 plants during the infectious process of $P$. oryzae contributed to the higher concentration of MDA and high EL values. The high concentration of ROS in the roots of tomato plants infected by $F$. oxysporum f. sp. lycopersici resulted in increased lipid peroxidation (51). According to Mandal et al. (51), a less efficient antioxidative system, particularly a decrease in CAT activity, explained the high level of damage caused by $F$. oxysporum f. sp. lycopersici. In the present study, the CAT activity was lower only in plants of BR 18 infected by P. oryzae.

The extent of the cellular damage caused by the oxidative stress related to the plant response against the pathogen infection can be estimated by the products of the peroxidation of membrane lipids (51). The MDA produced during lipid peroxidation is an indicator of cellular damage that results in an increase in EL (19). Any type of cellular stress, such as the action of nonselective toxins produced by $P$. oryzae, which are highly cytotoxic to rice (62) and possibly also to wheat, can cause rapid lipid peroxidation of the plasma membrane by $\operatorname{ROS}(28,44)$. In the present study, the MDA concentration was higher in the leaves of the inoculated plants of BRS 229 than the noninoculated plants only at 48 hai. As a result of the lower lipid peroxidation, the increase in EL was less pronounced in the plants from this cultivar than in plants from BR 18 , which can be linked to the reduced blast severity observed on the leaves of plants of the former cultivar. The higher activities of SOD, POX, APX, GST, and GR in the leaves of the inoculated plants of BRS 229 compared with inoculated plants of BR 18 at 96 hai resulted in lower concentrations of $\mathrm{O}_{2}^{-}$and $\mathrm{H}_{2} \mathrm{O}_{2}$, thereby limiting the cellular damages possibly caused by these ROS.

The results of the present study indicate that a more efficient antioxidative system in the removal of the excess of ROS generated during the infectious process of $P$. oryzae limits the cellular damage, thereby contributing to a greater resistance to blast. Further research that aims to investigate the antioxidative system in the most productive wheat cultivars will play a pivotal role in the development of biochemical markers that can be used in breeding programs to select resistant or tolerant cultivars that can be grown in areas in which severe epidemics of blast occur.

\section{ACKNOWLEDGMENTS}

This study was supported by grants from CAPES, the National Council for Scientific and Technological Development (CNPq), and FAPEMIG to F. A. Rodrigues. We thank the CNPq for the fellowship to F. A. Rodrigues, the CNPq for support to D. Debona and J. A. Rios, and D. Lau and M. Só e Silva (EMBRAPA-Centro Nacional de Pesquisa de Trigo) for providing the wheat seed from the cultivars used in this study. 


\section{LITERATURE CITED}

1. Agrawal, G. K., Jwa, N. S., and Rakwal. R. 2002. A pathogen-induced novel rice (Oryza sativa L.) gene encodes a putative protein homologous to type II glutathione-S-transferases. P Sci. 163:1153-1160.

2. Agrawal, G. K., Rakwal, R., Jwa, N. S., and Agrawal, V. P. 2002. Effects of signaling molecules, protein phosphatase inhibitors and blast pathogen (Magnaporthe grisea) on the mRNA level of a rice (Oryza sativa L.) phospholipid hydroperoxide glutathione peroxidase (OsPHGPX) gene in seedling leaves. Gene 283:227-236.

3. Anderson, D., Prasad, K., and Stewart, R. 1995. Changes in isozyme profiles of catalase, peroxidase and glutathione reductase during acclimation to chilling in mesocotyls of maize seedlings. Plant Physiol. 109:1247-1257.

4. Anderson, J. V., and Davis, D. G. 2004. Abiotic stress alters transcript profiles and activity of glutathione-S-transferase, glutathione peroxidase, and glutathione reductase in Euphorbia esula. Physiol. Plant. 120:421433.

5. Apel, K., and Hirt, H. 2004. Reactive oxygen species: Metabolism, oxidative stress, and signal transduction. Annu. Rev. Plant Biol. 55:373-399.

6. Arora, A., Sairam, R. K., and Srivastava, G. C. 2002. Oxidative stress and antioxidative system in plants. Curr. Sci. 82:1227-1238.

7. Arruda, M. A., Bueno, C. R. N. C., Zamprogno, K. C., Lavorenti, N. A., and Urashima, A. 2005. Reação do trigo a Magnaporthe grisea nos diferentes estádios de desenvolvimento. Fitopatol. Bras. 30:121-126.

8. Asada, K. 1992. Ascorbate peroxidase: a hydrogen peroxide-scavenging enzyme in plants. Physiol. Plant. 85:235-241.

9. Asada, K. 1994. Production and action of active oxygen species in photosynthetic tissues. Pages 77-103 in: Causes of Photooxidative Stress and Amelioration of Defense System in Plants. C. H. Foyer and P. M. Mullineaux, eds. CRC Press, Boca Raton, FL.

10. Beauchamp, C., and Fridovich, I. 1971. Superoxide dismutase: improved assays and an assay applicable to acrylamide gels. Anal. Biochem. 44:276-287.

11. Boveris, A. 1984. Determination of the production of superoxide radicals and hydrogen peroxide in mitochondria. Methods Enzymol. 105:429-435.

12. Bowler, C., Van Montagu, M., and Inze, D. 1992. Superoxide dismutase and stress tolerance. Annu. Rev. Plant Physiol. Plant Mol. Biol. 43:83116.

13. Bradford, M. N. 1976. A rapid and sensitive method for the quantitation of microgram quantities of protein utilizing the principle of protein-dye binding. Anal. Biochem. 72:248-254.

14. Cakmak, L., and Horst, W. J. 1991. Effect of aluminum on lipid peroxidation, superoxide dismutase, catalase, and peroxide activity in root tip of soybean (Glycine max). Plant Physiol. 83:463-468.

15. Cakmak, I., and Marschner, H. 1992. Magnesium deficiency and high light intensity enhance activities of superoxide dismutase, ascorbate peroxidase and glutathione reductase in bean leaves. Plant Physiol. 98:1222-1227.

16. Carlberg, C., and Mannervik, B. 1985. Glutathione reductase. Methods Enzymol. 113:488-495.

17. Chance, B., and Maehley, A. C. 1955. Assay of catalases and peroxidases. Methods Enzymol. 2:764-775.

18. Cruz, M. F. A., Prestes, A. M., Maciel, J. L. N., and Scheeren, P. L. 2010. Resistência parcial à brusone de genótipos de trigo comum e sintético nos estádios de planta jovem e de planta adulta. Trop. Plant Pathol. 35:24-31.

19. Dallagnol, L. J., Rodrigues, F. A., DaMatta, F. M., Mielli, M. V. B., and Pereira, S. C. 2011. Deficiency in silicon uptake affects cytological, physiological, and biochemical events in the rice-Bipolaris oryzae interaction. Phytopathology 101:92-104.

20. Del Longo, O. T., González, C. A., Pastori, G. M., and Trippi, V. S. 1993. Antioxidant defences under hyperoxygenic and hyperosmotic conditions in leaves of two lines of maize with differential sensitivity to drought. Plant Cell Physiol. 34:1023-1028.

21. Díaz-Vivancos, P., Clemente-Moreno, M. J., Rubio, M., Olmos, E., García, J. A., Martínez-Gómez, P., and Hernandéz, J. A. 2008. Alteration in the chloroplastic metabolism leads to ROS accumulation in pea plants in response to plum pox virus. J. Exp. Bot. 59:2147-2160.

22. Dixon, D. P., Skipsey, M., and Edwards, R. 2010. Roles for glutathione transferases in plant secondary metabolism. Phytochemistry 71:338-350.

23. Droog, F. 1997. Plant glutathione-S-transferases, a tale of theta and tau. J. Plant Growth Regul. 16:95-107.

24. Ehsani-Moghaddam, B., Charles, M. T., Carisse, O., and Khanizadeh, S. 2006. Superoxide dismutase responses of strawberry cultivars to infection by Mycosphaerella fragariae. J. Plant Physiol. 163:147-153.

25. El-Zahabi, H. M., Gullner, G., and Királi, Z. 1995. Effects of powdery mildew infection of barley on the ascorbate-glutathione cycle and other antioxidants in different host-pathogen interactions. Phytopathology 85:1225-1230.

26. Eshdat, Y., Holland, D., Faltin, Z., and Ben-Hayyim, G. 1997. Plant glutathione peroxidases. Physiol. Plant. 100:234-240.

27. Foyer, C. H., and Halliwell, B. 1976. The presence of glutathione and glutathione reductase in chloroplasts: a proposed role in ascorbic acid metabolism. Planta 133:21-25.

28. Fu, J., and Huang, B. 2001. Involvement of antioxidants and lipid peroxidation in the adaptation of two cool-season grasses to localized drought stress. Environ. Exp. Bot. 45:105-114.

29. García-Limones, C., Hervás, A., Navas-Cortés, J. A., Jiménez-Díaz, R. M., and Tena, M. 2002. Induction of antioxidant enzyme system and other oxidative stress markers associated with compatible and incompatible interactions between chickpea (Cicer arietinum L.) and Fusarium oxysporum f. sp. ciceris. Physiol. Mol. Plant Pathol. 61:325-337.

30. Gay, C., and Gerbicki, J. M. 2000. A critical evaluation of sorbitol on the ferric-xylenol orange hydroperoxide assay. Anal. Biochem. 284:217-220.

31. Giannopolitis, C. N., and Ries, S. K. 1977. Superoxide dismutases I. Occurrence in higher plants. Plant Physiol. 59:309-314.

32. Goulart, A. C. P., and Paiva, F. A. 1992. Incidência da brusone (Pyricularia grisea) em diferentes cultivares de trigo (Triticum aestivum) em condições de campo. Fitopatol. Bras. 17:321-325.

33. Goulart, A. C. P., and Paiva, F. A. 1993. Avaliação de fungicidas no controle da brusone (Pyricularia grisea) do trigo (Triticum aestivum). Fitopatol. Bras. 18:167-73.

34. Goulart, A. C. P., Sousa, P. G., and Urashima, A. S. 2007. Danos em trigo causados pela infecção de Pyricularia oryzae. Summa Phytopathol. 33:358-363.

35. Govrin, E. M., and Levine, A. 2000. The hypersensitive response facilitates plant infection by the necrotrophic pathogen Botrytis cinerea. Curr. Biol. 10:751-757.

36. Habig, W. H., Pabst, M. J., and Jakoby, W. B. 1974. Glutathione-Stransferases. The first enzymatic step in mercapturic acid formation. J. Biol. Chem. 249:7130-7139.

37. Harrach, B. D., Fodor, J., Pogány, M., Preuss, J., and Barna, B. 2008. Antioxidant, ethylene and membrane leakage responses to powdery mildew infection of near-isogenic barley lines with various types of resistance. Eur. J. Plant Pathol. 121:21-33.

38. Heath, R. L., and Packer, L. 1968. Photoperoxidation in isolated chloroplast. I. Kinetics and stoichometry of fatty acid peroxidation. Arch. Biochem. Byophys. 125:189-198.

39. Hernández, J. A., Talavera, J. M., Martínez-Gómez, P., Dicenta, F., and Sevilla, F. 2001. Response of antioxidative enzymes to plum pox virus in two apricot cultivars. Physiol. Plant. 111:313-321.

40. Hiraga, S., Sasaki, K., Ito, H., Ohashi, Y., and Matsui, H. 2001. A large family of class III plant peroxidases. Plant Cell Physiol. 42:462-468.

41. Hong-xia, L. Zhi-yong, X., and Zeng-yan, Z. 2011. Changes in activities of antioxidant-related enzymes in leaves of resistant and susceptible wheat inoculated with Rhizoctonia cerealis. Agric. Sci. China 10:526-533.

42. Hückelhoven, R., Dechert, C., Trujillo, M., and Kogel, K. H. 2001. Differential expression of putative cell death regulator genes in nearisogenic, resistant and susceptible barley lines during interaction with the powdery mildew fungus. Plant Mol. Biol. 47:739-748.

43. IRRI. 1996. Standard Evaluation System for Rice. International Rice Research Institute, Los Banos, Philippines.

44. Iturbe-Ormaetxe, I., Escuredo, P., Arrese-Igor, C., and Becana, M. 1998. Oxidative damage in pea plants exposed to water deficit or paraquat. Plant Physiol. 116:73-181.

45. Kar, M., and Mishra, D. 1976. Catalase, peroxidase, and polyphenoloxidase activities during rice leaf senescence. Plant Physiol. 57:315-319.

46. Kuo, M. C., and Kao, C. H. 2003. Aluminium effects on lipid peroxidation and antioxidative enzyme activity in rice leaves. Biol. Plant. 46:149-152.

47. Kuzniak, E., and Sklodowska, M. 2005. Fungal pathogen-induced changes in the antioxidant systems of leaf peroxisomes from infected tomato plants. Planta 222:192-200.

48. Lima, A. L. S., DaMatta, F. M., Pinheiro, H. A., Totola, M. R., and Loureiro, M. E. 2002. Photochemical responses and oxidative stress in two clones of Coffea canephora under water deficit conditions. Environ. Exp. Bot. 47:239-247.

49. Lin, C. H., Yang, S. L., and Chung, K. R. 2009. The YAP1 homologmediated oxidative stress tolerance is crucial for pathogenicity of the necrotrophic fungus Alternaria alternata in citrus. Mol. Plant-Microbe Interact. 22:942-952.

50. Magbanua, Z. V., De Moraes, C. M., Brooks, T. D., Williams, W. P., and Luthe, D. S. 2007. Is catalase activity one of the factors associated with maize resistance to Aspergillus flavus? Mol. Plant-Microbe Interact. 20:697-706.

51. Mandal, S., Mitra, A., and Mallick, N. 2008. Biochemical characterization of oxidative burst during interaction between Solanum lycopersicum and Fusarium oxysporum f. sp. lycopersici. Physiol. Mol. Plant Pathol. 72:56-61.

52. Marrs, K. A. 1996. The functions and regulation of glutathione-S-transferases in plants. Annu. Rev. Plant Physiol. Plant Mol. Biol. 47:127-158. 
53. Mehdy, M., Sharma, Y. K., Sathasivan, K., and Bays, N. W. 1996. The role of activated oxygen species in plant disease resistance. Physiol. Plant. 98:365-374.

54. Misra, H. P., and Fridovich, I. 1971. The generation of superoxide radical during autoxidation of ferredoxins. J. Biol. Chem. 246:6886-6890.

55. Mittler, R. 2002. Oxidative stress, antioxidants and stress tolerance. Trends Plant Sci. 7:405-410.

56. Miyagawa, Y., Tamoi, M., and Shigeoka, S. 2000. Evaluation of defence system in chloroplasts to photooxidative stress caused by paraquat using transgenic tobacco plants expressing catalase from Escherichia coli. Plant Cell Physiol. 41:311-320.

57. Mohammadi, M., and Karr, A. L. 2001. Superoxide anion generation in effective and ineffective soybean root nodules. J. Plant Physiol. 158:10231029.

58. Nagalakshmi, N., and Prasad, M. N. V. 2001. Responses of glutathione cycle enzymes and glutathione metabolism to copper stress in Scenedesmus bijugatus. Plant Sci. 160:291-299.

59. Nakano, Y., and Asada, K. 1981. Hydrogen peroxide is scavenged by ascorbate-specific peroxidase in spinach chloroplasts. Plant Cell Physiol. 22:867-880.

60. Noctor, G., and Foyer, C. H. 1998. Ascorbate and glutathione: keeping active oxygen under control. Annu. Rev. Plant Physiol. Plant Mol. Biol. 49:249-279.

61. Oksanen, E., Häikkiö, E., Sober, J., and Karnosky, D. F. 2003. Ozoneinduced $\mathrm{H}_{2} \mathrm{O}_{2}$ accumulation in field-grown aspen and birch is linked to foliar ultrastructure and peroxisomal activity. New Phytol. 161:791-799.

62. Ou, S. H. 1985. Rice Diseases. Commonwealth Mycological Institute, Kew, UK.

63. Palma, J. M., Sandalio, L. M., Corpas, F. J., Romero-Puertas, M. C., McCarthy, I., and del Río, L. A. 2002. Plant proteases, protein degradation, and oxidative stress: role of peroxisomes. Plant Physiol. Biochem. 40:521-530.

64. Pickett, C. B., and Lu, A. Y. H. 1989. Glutathione-S-transferases: Gene structure, regulation, and biological function. Annu. Rev. Biochem.
58:743-764.

65. Quan, L. J., Zhang, B., Shi, W. W., and Li, H. Y. 2008. Hydrogen peroxide in plants: a versatile molecule of the reactive oxygen species network. J. Integr. Plant Biol. 50:2-18.

66. Rauyaree, P., Choi, W., Fang, E., Blackmon, B., and Dean, R. 2001. Genes expressed during early stages of rice infection with the rice blast fungus Magnaporthe grisea. Mol. Plant Pathol. 2:347-354.

67. Reis, E. M., and Casa, R. T. 2005. Doenças do trigo. Pages 631-638 in: Manual de Fitopatologia. Doenças de Plantas Cultivadas. H. Kimati, L. Amorim, J. A. M. Rezende, A. Bergamin Filho, and L. E. A., Camargo, eds. Ceres, São Paulo, Brazil.

68. Sarowar, S., Kim, E. N., Kim, Y. J., Ok, S. H., Kim, K. D., Hwang, B. K., and Shin, J. S. 2005. Overexpression of a pepper ascorbate peroxidaselike 1 gene in tobacco plants enhances tolerance to oxidative stress and pathogens. Plant Sci. 169:55-63.

69. Scandalios, J. G. 2011. Wheat resistance to leaf blast mediated by silicon. Australas. Plant Pathol. 40:28-38.

70. Schaedle, M., and Bassham, J. A. 1977. Chloroplast glutathione reductase. Plant Physiol. 59:1011-1012.

71. Takesawa, T., Ito, M., Kanzaki, H., Kameya, N., and Nakamura, I. 2002. Over-expression of glutathione-S-transferase in transgenic rice enhances germination and growth at low temperature. Mol. Breed. 9:93-101.

72. Urashima, A. S., and Kato, H. 1994. Varietal resistance and chemical control of wheat blast fungus. Summa Phytopathol. 20:107-112.

73. Urashima, A. S., Lavorenti, N. A., Goulart, A. C. P., and Mehta, Y. R. 2004. Resistance spectra of wheat cultivars and virulence diversity of Magnaporthe grisea isolates in Brazil. Fitopatol. Bras. 29:511-518.

74. Willekens, H., Inzé, D., Van Montagu, M., and Van Camp, W. 1995. Catalases in plants. Mol. Breed. 1:207-228.

75. Xavier Filha, M. S., Rodrigues, F. A., Domiciano, G. P., Oliveira, H. V., Silveira, P. R., and Moreira, W. R. 2011. Wheat resistance to leaf blast mediated by silicon. Australas. Plant Pathol. 40:28-38.

76. Zadoks, J. C., Chang, T. T., and Konzak, C. F. 1974. A decimal code for the growth stages of cereals. Weed Res. 14:415-421. 